\title{
IMPLEMENTASI MODEL PEMBELAJARAN TWO STAY-TWO STRAY (TS- TS) UNTUK MENINGKATKAN PRESTASI BELAJAR SISWA
}

\author{
Muhammad Musfiatul Wardi 1,Mutia Hidayatullah ${ }^{2}$ \\ 1, 2Program Studi PGMI, Universitas Muhammadiyah Mataram, Indonesia \\ $\underline{\text { musfet14@gmail.com }}^{1}$, muthiahidayatuloh2@gmail.com $^{2}$
}

\section{INFO ARTIKEL}

Riwayat Artikel:

Diterima: 02-05-2021

Disetujui: 30-10 -2021

\section{Kata Kunci:}

Orang Tua,

Buruh Migrant,

Prestasi Belajar

Keywords:

Two Stay-Two Stray (Ts-Ts)

Learning Model,

Learning achievement, Fiqh

\section{A. LATAR BELAKANG}

UU No. 20 Tahun 2003 Pendidikan Nasional berfungsi mengembangkan kemampuan dan membentuk waktu serta peradaban bangsa yang bermartabat dalam rangka mencerdaskan kehidupan bangsa. Berdasarkan fungsi pendidikan di atas maka peran pendidik menjadi kunci keberhasilan dalam misi pendidikan dan pembelajar di sekolah.

Sistem pendidikan menjadi bagian yang tak terpisahkan dari kehidupan sosial budaya dan

\section{ABSTRAK}

Abstrak: Guru MI Nurul Iman NW Kembang Kerang, khususnya guru mata pelajaran fiqih masih menggunakan metode pembelajaran konvensional atau metode pembelajaran ceramah, dimana guru hanya menyampaikan materi tanpa memahami bakal kemampuan siswa sehingga mengakibatkan nilai prestasi belajar pada mata pelajaran fiqih ini relatif rendah. Penelitian ini menggunakan metode Penelitian class action (PTK) yang berlangsung dalam dua siklus yang telah direncakan yang dibagi dalam empat tahapan yaitu : tahap perencanaan, tahap pelaksanaan, tahap pengamatan (observasi), dan tahap refleksi. Dalam penelitian ini penggumpulan data menggunakan instrumen wawancara, observasi dan tes. Dan kemudian dianalisis dengan menggunakan pedoman yang telah ditetapkan tanpa menggunakan aplikasi statistik. Hasil penelitian menunjukkan bahwa dari persentasi peserta didik yang memiliki prestasi berkategori tinggi meningkat dari 10 pada siklus I menjadi 14,8 pada siklus II, dan prestasi belajar peserta didik yang terdiri dari 16 jumlah peserta didik terdapat 10 peserta didik berhasil mencapai nilai $\geq 70$ dengan presentasi ketuntasan klasikal 62,5\% dan rata-rata hasil belajar 70,62. Semsentara pada siklus II diperoleh data ketuntasan klasikal sebesar $100 \%$ atau 16 peserta didik memperoleh nilai $\geq 70$ dengan rata-rata hasil belajar 83,75. Hasil observasi juga menunjukkan aktivitas peserta didik dan guru mengalami peningkatan dari siklus I ke siklus II, pada siklus I aktivitas peserta didik dan guru berkategori cukup aktif, sedangkan pada siklus II aktif.

\begin{abstract}
:
MI teacher Nurul Iman NW Kembang Kerang, especially Fiqh subject teachers still use conventional learning methods or lecture learning methods, where teachers only deliver material without understanding the future abilities of students, resulting in relatively low learning achievement scores in fiqh subjects. This study uses the Class Action Research (CAR) method which takes place in two planned cycles which are divided into four stages, namely: the planning stage, the implementation stage, the observation stage, and the reflection stage. In this study data collection using interview, observation and test instruments. And then analyzed using predefined guidelines without using statistical applications. The results showed that the percentage of students who had high achievement categories increased from 10 in the first cycle to 14.8 in the second cycle, and the learning achievement of students consisting of 16 students, there were 10 students who managed to achieve a score of 70 with presentations. classical completeness is $62.5 \%$ and the average learning outcome is 70.62. Meanwhile, in the second cycle, 100\% classical completeness data was obtained or 16 students scored 70 with an average learning outcome of 83.75. The results of observations also show that the activities of students and teachers have increased from cycle I to cycle II, in cycle I the activities of students and teachers are categorized as quite active, while in cycle II they are active.
\end{abstract}


(ceramah). Menurut Nur Hadi dan Agus Senduk ada tiga mainstream yang perlu di soroti, yaitu : pembaharuan kurikulum, peningkatan kualitas pembelajaran, dan efektivitas pembelajaran. Kurikulum pendidikan harus konprehensif terhadap dinamika sosial, relevan, tidak tumpang tindih, dan mampu mengakomodasikan keberagaman keperluan dan kemajuan tekhnologi. Kualitas pembelajaran harus ditingkatkan untuk memperbaiki kualitas hasil pendidikan. Secara mikro harus ditemukan strategi atau pendekatan pembelajaran yang efektif di kelas, yang lebih memberdayakan potensi siswa.

Pendidikan di sekolah tidak dapat dilepaskan dari proses pembelajaran dan interaksi antar guru dan siswa. Pembelajaran merupakan suatu proses yang rumit karena tidak sekedar menyerap informasi dari guru, tetapi juga melibatkan berbagai kegiatan dan tindakan yang harus dilakukan untuk mencapai hasil belajar yang baik.

Guru merupakan kunci dalam meningkatkan mutu Pendidikan dan bertanggung jawab untuk mengatur, mengarahkan, dan menciptakan suasana yang mendorong siswa untuk melaksanakan kegiatan-kegiatan di kelas. Untuk menunjang tugas tersebut diperlukan pemilihan model yang tepat dan sesuai dengan materi atau konsep yang akan diajarkan. Model mengajar yang dipakai guru akan berpengaruh juga terhadap cara belajar siswa yang mana setiap siswa mempunyai cara belajar yang berbeda dengan cara belajar siswa yang lainnya.

Pada proses belajar mengajar guru harus memiliki strategi agar siswa dapat belajar secara efisien dan efektif. Salah satu langkahnya adalah harus menguasai tehnik-tehnik penyajian (metode mengajar), tehnik penyajian pelajaran adalah suatu pengetahuan tentang cara-cara mengajar yang dipergunakan oleh guru atau instruktur. misalnya guru memerlukan berbagai tujuan dicapainya tujuan pembelajaran, maka guru perlu mengenal dan mengawasi dengan baik sifat-sifat dari setiap tehnik penyajian sehingga mampu mengkombinasikan penggunaan beberapa tehnik penyajian sekaligus untuk mencapai beberapa tujuan yang telah dirumuskan dan tidak terasa jauh berbeda antara perubahan dari tehnik yang satu dan tehnik yang lain.

Sebagian besar masalah yang dihadapi sistem pendidikan di Indonesia berujung pada dua persoalan utama yaitu kurikulum dan metodologi pembelajaran. Kurikulum berfungsi sebagai kompas dalam arti penentu arah jalannya proses pembelajaran yang akan digunakan. Sementara itu metodologi pembelajaran adalah ujung tombaknya. Kurikulum tidak mungkin dapat berjalan dengan baik dan benar jika tidak diikuti oleh sistem dan metode pembelajaran yang sistematika dan terpadu.

Dari segi material, konsep kurikulum yang berkembang saat ini dirasa sudah cukup untuk dijadikan standar pembelajaran di sekolah setidaknya untuk sementara waktu ini. Hal ini tidak sama halnya dengan metode pembelajaran yang digunakan di sekolah-sekolah pada umumnya bersifat konvensional dan klasik. Yaitu guru bercerita dan murid-murid mendengar dan mencatat, guru memberi dan murid menerima.

Contonya Dalam pembelajaran Fiqih, tidak hanya terjadi proses interaksi antara guru dan anak didik di dalam kelas. Namun pembelajaran dilakukan juga dengan berbagai interaksi, baik di lingkungan kelas maupun musholla sebagai tempat praktek-praktek yang menyangkut ibadah. Guru lebih memfokuskan diri pada upaya pemindahan pengetahuan ke dalam kepala siswa tanpa memperhatikan bahwa ketika siswa memasuki kelas, siswa mempunyai bekal kemampuan dan pengetahuan yang tidak sama. Siswa hanya ditempatkan sebagai objek sehingga siswa menjadi pasif dan tenggelam ke dalam kondisi belajar yang kurang merangsang aktifitas belajar yang optimal.

Belajar Fiqih tidak hanya sekedar learning to know (mengetahui), melainkan harus ditingkatkan meliputi learning to do (memahami). Dalam pembelajaran Fiqih guru lebih banyak menyampaikan sejumlah ide atau gagasan fiqih kegiatan siswa mendapat lebih banyak porsi dibandingkan dengan guru, bahkan mereka harus dominan dalam kegiatan belajar mengajar. Sehingga ketika siswa mendapatkan nilai yang relatif rendah guru sebagai faktor utama harus berusaha meningkatkan lagi kualitas belajarnya agar siswa lebih aktif dalam kegiatan proses belajar mengajar tersebut.

Kondisi permasalahan pembelajaran seperti yang diuraikan di atas terjadi di Madrasah Ibtidaiyah Nurul Iman NW Kembang Kerang khususnya di kelas $V$, sehingga siswa yang berpartisipasi aktif dalam pembelajaran kurang. Partisipasi siswa hanya pada saat mengerjakan LKS, akan tetapi selama proses pemberian konsep, siswa lebih banyak menyimak dan mendengarkan informasi dari guru. Situasi seperti itu selalu terulang dari materi yang satu ke materi yang lain. Untuk mengantisipasinya guru biasanya memberikan Pekerjaan Rumah (PR). Dengan memberikan tugas di rumah, guru berharap siswa lebih banyak membaca dan memahami materi, namun hasilnya masih belum memuaskan.

Hal ini terlihat dari hasil dokumentasi nilainilai mata pelajaran Fiqih untuk beberapa materi 
yang berbeda dikelas $\mathrm{V}$, dimana hanya sedikit siswa yang tuntas belajar nilainya diatas Kriteria Ketuntasan Minimal (KKM : $\geq 70$ ), yaitu rata-rata sekitar $60 \%$.

\section{A. METODE PENELITIAN}

Penelitian ini merupakan class room action research, yaitu satu action research Dimana penelitian yang dilakukan oleh guru di dalam kelasnya sendiri melalui refleksi diri dengan tujuan untuk memperbaiki kinerja sebagai seorang guru, sehingga proses pembelajaran dapat berjalan dengan baik dan hasil belajar siswa meningkat. Suharjono memberi pengertian penelitian tindakan kelas sebagai penelitian yang langsung menerapkan perlakuan dengan cara hati-hati, seraya mengikuti proses serta dampak perlakuan yang dimaksud. Penelitian Tindakan termasuk kelompok penelitian eksperimen yakni penelitian yang dimaksudkan untuk mengumpulkan informasi atau data tentang akibat dari adanya suatu perlakuan atau treatment. Permasalahan yang dihadapi atau dialami oleh guru, maka solusinya dirancang berdasarkan kajian teori pembelajaran.

Penelitian ini dilaksanakan di MI Nurul Iman NW Kembang Kerang di kelas V, dengan jumlah siswa perempuan sebanyak 10 orang dan siswa laki-laki sebanyak 6 orang yang keseluruhannya sebanyak 16 orang .

\section{A. Sasaran Penelitian}

Sasaran penelitian ini yaitu siswa kelas V di MI NW Kembang Kerang dengan jumlah siswa 16 orang. Penelitian ini dilakukan di madrasah tersebut dikarenakan peneliti melihat madrasah ini jarang sekali menggunakan metode-metode pembelajaran yang menarik untuk meningkatkan minat belajar siswanya.

\section{B. Rencana Tindakan}

Penelitian ini direncanakan dalam siklussiklus dengan masing- masing siklus terdiri dari perencanaan, pelaksanaan, pengamatan dan refleksi. Keempat tahap tersebut membentuk sebuah siklus yang beruntun dan selanjutnya kembali ke langkah semula dan seterusnya.

Berdasarkan gambar alur di atas, beberapa tahapan dalam satu siklus mencerminkan satu rangkaian yang tak terpisahkan. Alur di atas dalam operasionalnya penelitian ini secara rinci dapat dijelaskan sebagai berikut :

\section{Perencanaan}

Dalam pelaksanaan tindakan ini peneliti melaksanakan skenario pembelajaran yang sesuai dengan Rencana Pelaksanaan Pembelajaran yang telah disusun sebelumnya. Untuk perencanaan pelajaran fiqih direncanakan menggunakan metode pelajaran two stay two stray (TS-TS).

Penelitian ini dilakukan sebagai upaya untuk meningkatkan hasil belajar siswa yang direncanakan dalam suatu siklus. Adapun rencana tindakan dalam penelitian ini adalah sebagai berikut :

a. Membuat skenario pembelajaran yang berisi kegiatan guru, kegiatan siswa, metode, dan alokasi waktu serta membuat rencana pembelajaran (RPP) sebagai persiapan guru dalam setiap pertemuan.

b. Pengaturan waktu dalam proses belajar mengajar sesuai dengan rincian waktu dalam rencana pelaksanaan pembelajaran.

c. Mempersiapkan fasilitas dan sarana pendukung yang diperlukan dalam pelaksanaan pembelajaran.

d. Membuat alat untuk mencatat dan mengumpulkan data seperti lembar observasi yang memuat tentang indikator perilaku siswa dan guru selama proses belajar mengajar.

Dalam kegiatan pembelajaran dengan menerapkan metode pembelajaran dilakukan dengan siklus pembelajaran yang terdiri dari perencanaan, pelaksanaan tindakan, observasi, dan refleksi yang diikuti dengan siklus berikutnya. Hal ini dilakukan dengan maksud memperoleh hasil belajar yang maksimal mengenai penerapan metode pembelajaran.

\section{Pelaksanaan Tindakan}

Pelaksanaan tindakan adalah perlakuan yang dilaksanakan guru berdasarkan perencanaan yang telah disusun. Pelaksanaan tindakan yang dilakukan guru adalah perlakuan yang dilaksanakan yang diarahkan sesuai dengan perencanaan.

Pada tahap ini dilakukan pelaksanaan yang sesuai dengan perencanaan yang telah dibuat sebelumnya, adapun peran peneliti disini adalah:

a. Melaksanakan perencanaan yng telah disusun sebelumnya yakni memberikan penjelasan sesuai dengan materi pelajaran fiqih.

b. Mengarahkan siswa untuk mengikuti aturan metode pelajaran two stay-two stray (TS-TS) untuk meningkatkan prestasi belajar siswa

c. Bekerja dengan maksimal dalam melaksanakan tindakan yang telah direncanakan

3. Pengamatan Tindakan

Pengamatan atau pemantauan ini dilakukan untuk mengumpulkan informasi tentang proses pembelajaran yang dilakukan guru sesuai dengan tindakan yang telah disusun. Melalui pengumpulan informasi, observer dapat mencatat berbagai 
kelemahan dan kekuatan yang dilakukan guru dalam melaksanakan tindakan sehingga hasilnya dapat dijadikan masukan ketika guru melakukan refleksi.

Kegiatan observasi dilakukan secara kontinyu setiap kali pembelajaran berlangsung, dalam pelaksanaan tindakan dengan mengamati kegiatan guru dan aktivitas siswa. Kegiatan guru yang dimaksud adalah bagaimana guru melaksanakan semua langkah-langkah dalam proses pembelajaran, bagaimana semangat dan antusias siswa ketika menerima pelajaran khususnya pada saat diterapkannya strategi two stay-two stray (TSTS).

\section{Refleksi}

Refleksi adalah aktifitas-aktifitas melihat berbagai kekurangan yang dilaksanakan guru selama tindakan. Refleksi dilakukan dengan melakukan diskusi dengan observer biasanya.

Pada tahap ini, peneliti bersama guru yang bertindak sebagai observer mengkaji hasil observasi dari evaluasi yang diperoleh dan dari hasil angket yang diberikan kepada siswa. Dari hasil analisis tersebut peneliti memperbaiki berbagai kekurangan yang terjadi pada siklus I. Cara pengajaran juga di tambah dan disesuaikan dengan strategi yang digunakan.

\section{Jenis instrumen dan cara penggunaannya}

Instrument penelitian adalah alat yang dapat digunakan untuk mengumpulkan data penelitian karena alat atau instrument ini mencerminkan juga cara pelaksanaannya maka sering juga disebut dengan tehnik penelitian. Penelitian sebagai suatu cara ilmiah dalam memecahkan masalah termasuk PTK selamanya berhubungan dengan instrumen pengumpulan data, tanpa instrumen yang tepat penelitian tidak akan menghasilkan sesuatu yang diharapkan. ${ }^{1}$

Jadi instrumen penelitian merupakan suatu alat bantu yang digunakan oleh peneliti untuk mengumpulkan data-data atau informasi dalam penelitian. Dalam hal ini maka instrumen yang digunakan adalah sebagai berikut :

1. Observasi

Observasi merupakan tehnik mengumpulkan data dengan cara mengamati setiap kejadian yang sedang berlangsung dan mencatatnya dengan alat observasi tentang hal-hal yang akan di amati atau diteliti. Dalam Penelitian Tindakan Kelas observasi bisa dilakukan untuk memantau guru dan untuk memantau siswa sebagai alat pemantau kegiatan guru, observasi digunakan untuk mencatat setiap tindakan yang dilakukan guru sesuai dengan masalah dalam Penelitian Tindakan Kelas itu sendiri.

Adapun beberapa instrumen yang digunakan dalam penelitian ini diantaranya:

a. Lembar Observasi Aktivitas Guru

Pada lembar observasi kegiatan guru termuat sejumlah aktivitas yang dilakukan oleh guru pada masing-masing pertemuan dari setiap siklus yang bertujuan untuk melihat tingkatan aktivitas guru didalam menerapkan metode two stay-two stray (TS-TS).

b. Lembar Observasi Aktivitas Siswa

Pada lembar observasi aktivitas siswa termuat sejumlah aktivitas yang dilakukan oleh siswa selama proses pembelajaran berlangsung. Lembar observasi aktivitas siswa dalam penelitian ini terdiri dari 6 indikator setiap indikator terdiri dari 3 deskriptor.

Selain itu dalam penelitian ini peneliti juga secara langsung ikut serta ditengah-tengah berlangsungnya proses pembelajaran dan senantiasa berada di lingkungan lokasi penelitian serta akan dibantu oleh guru mata pelajaran fiqih untuk memperoleh data tentang keadaan geografis Madrasah Ibtidaiyah Nurul Iman NW Kembang Kerang dan aktivitas siswa kelas V Madrasah Ibtidaiyah Nurul Iman NW Kembang Kerang yang mencakup beberapa hal sebagai berikut:

a. Displin dan kesiapan belajar siswa.

b. Antusias siswa dalam mengikuti pembelajaran.

c. Respon siswa dalam mengikuti pembelajaran.

d. Aktivitas siswa dalam kegiatan pembelajaran.

2. Wawancara

Wawancara atau interview dapat diartikan sebagai tehnik mengumpulkan data dengan menggunakan bahasa lisan baik secara tatap muka ataupun melalui saluran media tertentu selain observasi. Wawancara atau interview merupakan instrument penelitian yang sering digunakan untuk mengmpulkan data dalam Penelitian Tindakan Kelas.

Adapun jenis-jenis wawancara diantaranya adalah:

a. Wawancara insidental adalah jenis wawancara yang dilaksanakan sewaktu-waktu bila dianggap perlu wawancara yang demikian juga dinamakan sebagai wawancara yang tidak formal.

b. Wawancara terencana adalah jenis wawancara yang dilaksanakan secara formal yang dilaksanakan secara terencana baik mengenai waktu pelaksanaannya, tempat dan topik yang akan dibicarakan.

Dalam penelitian ini, peneliti secara langsung berhadapan dan mewawancarai Kepala Madrasah 
Ibtidaiyah Nurul Iman NW Kembang Kerang untuk memperoleh informasi tentang latar belakang berdirinya Madrasah Ibtidaiyah Nurul Iman NW Kembang Kerang.

3. Tes

Tes instrument pengumpulan data untuk mengukur kemampuan siswa dalam aspek kognitif atau penguasaan materi pembelajaran. Sebagai alat ukur dalam proses evaluasi, tes harus memiliki dua kriteria yaitu Kriteria validitas dan reabilitas.

Tes ini dilakukan dengan tujuan untuk mengetahui peningkatan prestasi belajar siswa dengan penerapan model Pembelajaran Two StayTwo Stray (TS-TS).

a. Teknik Analisis Data

1) Menentukan data tes hasil belajar siswa

a) Ketuntasan individu

Untuk menentukan ketuntasan belajar siswa digunakan instrumen tes hasil belajar siswa yang meliputi produk, proses dan psikomotorik. Penentuan ketuntasan berdasarkan penilaian acuan patokan yaitu sejauh mana kemampuan yang ditargetkan dapat dikuasai oleh siswa dengan cara menghitung proporsi jumlah siswa yang menjawab benar dibagi dengan jumlah skor maksimumnya.

b) Ketuntasan klasikal

Ketuntasan belajar telah dinyatakan telah tercapai jika sekurang-kurangnya $85 \%$ dari jumlah siswa dalam kelas yang bersangkutan sudah memenuhi kriteria ketuntasan belajar individu ( perorangan ). Hal ini dapat dihitung dengan rumus:

Rumusnya adalah :

$$
\mathrm{KK}=\frac{P}{N} \times 100
$$

Keterangan :

$\mathrm{KK}=$ Ketuntasan Klasikal

$\mathrm{P}=$ jumlah siswa yang mempunyai nilai $\geq 50$

$\mathrm{N}=$ Jumlah Seluruh Siswa

c) Nilai Rata-Rata Kelas

$$
\begin{aligned}
& \mathrm{R}=\frac{\Sigma X}{N} \\
& \text { Keterangan : } \\
& \mathrm{R} \quad=\text { Nilai rata-rata } \\
& \Sigma \mathrm{X}=\text { Jumlah nilai yang diperoleh siswa } \\
& \mathrm{N} \quad=\text { banyaknya siswa yang ikut tes }
\end{aligned}
$$

2) Menentukan Skor Aktivitas Belajar Siswa Menghitung skor aktivitas belajar siswa dengan rumus:

$$
\text { AS }=\frac{\Sigma X}{N}
$$

Keterangan:

AS = Skor rata-rata aktivitas belajar siswa

$\mathrm{X}=$ Jumlah Skor Seluruh Siswa
$\mathrm{N}$ = Banyaknya Siswa ${ }^{2}$

Menentukan Skor Aktivitas Guru

Data aktivitas guru dianalisis dengan menentukan kategori aktivitas guru dengan berpedoman pada patokan atau standar berikut:

Tabel 3.1 Pedoman Kategori Aktivitas Guru

\begin{tabular}{|c|c|c|}
\hline NO & Skor Guru & Kategori \\
\hline 1 & Lebih dari 8 & Sangat aktif \\
\hline 2 & 6 sampai 8 & Aktif \\
\hline 3 & 4 sampai $<6$ & Cukup aktif \\
\hline & 0 sampai $<4$ & Kurang aktif \\
\hline
\end{tabular}

\section{B. HASIL DAN PEMBAHASAN}

Madrasah Ibtidaiyah Nurul Iman NW Kembang Kerang ini berdiri dilatarbelakangi oleh adanya kebutuhan dari masyarakat Kembang Kerang dan sekitarnya yang sangat membutuhkan adanya sekolah Islam yang bisa menanamkan nilainilai ajaran Islam sejak dini kepada anaknya. Terlebih lagi, diharapkan adanya tindak lanjut dari pendidikan Taman Kanak-Kanak Islam yang dimiliki oleh yayasan, sebagai lembaga tempatnya menitipkan dan mempercayakan anak-anaknya untuk dididik selama ini, Taman Kanak-Kanak yang berdiri sejak tahun 1996 ini didirikan oleh Yayasan Nahdatul Wathan bersama masyarakat dan remaja putri yang ada di Kembang Kerang. Visi dari madrasah ini adalah: Menjadi insan Qura'ani, yang Unggul dalam prestasi, disiplin dan berbudaya, sedangkan Misi Madrasah Ibtidaiyah Nurul Iman NW Kembang Kerang adalah sebagai berikut:

a. Menyelenggarakan pendidikan berbasis tahfizul Qura'an serta membentuk pribadi yang cerdas, jujur,amanah, terampil dan mandiri

b. Menyelenggarakan kegiatan pengembangan diri sehingga siswa dapat berkembang sesuai dengan minat dan bakatnya

c. Menanamkan akidah yang kuat melalui pembiasaan sholat dhuha berjamaah, gemar menghafal alqur'an, ucapan kalimat toyibah,dan perilaku islami.

Letak geografis Madrasah Ibtidaiyah Nurul Iman NW Kembang Kerang yang dimaksud adalah : gambaran umum lokasi lingkungan Madrasah Ibtidaiyah Nurul Iman NW Kembang Kerang yang berlokasi di lingkungan Kembang Kerang kecamatan batukliang. Madrasah Ibtidaiyah Nurul Iman NW Kembang Kerang terletak di tengah pemukiman warga, Madrasah Ibtidaiyah Nurul Iman NW Kembang Kerang ini memiliki 2 gedung

${ }^{2}$ Nana Sudjana, Penilaian Hasil Proses Belajar Mengajar ( Bandung: remaja rosdakarya. 2013)109 
gedung yang pertama terletak di sebelah utara dan gedung yang kedua berada di sebelah selatan jalan raya. Luas tanah dimiliki oleh, Madrasah Ibtidaiyah Nurul Iman NW Kembang Kerang sampai saat ini adalah $2.700 \mathrm{M}$.

\section{Keadaan Guru Madrasah Ibtidaiyah Nurul Iman NW Kembang}

Dalam proses pembelajaran, guru memiliki potensi yang sangat besar terutama dalam kemampuan mengajar, cara penyampaian materi serta menunjang tercapainya tujuan pendidikan yang diharapkan. Tugas guru sebagai profesi meliputi mendidik, mengajar, melatih, dan mengembangkan ilmu pengetahuandan teknologi, melatih mengembangkan keterampilanketerampilan pada siswa. Siswa dan sisiwi Madrasah Ibtidaiyah Nurul Iman NW Kembang kerang. sebagian besar di ajar oleh guru-guru honor (sukarela). Guru di Madrasah Ibtidaiyah Nurul Iman NW Kembang kerang sebagian besar merupakan orang-oarang yang bertempat tinggal di sekitar madrasah tersebut

Siswa merupakan subjek utama yang terlibat dalam proses pembelajaran di dalam kelas. Sehebat apapun seorang guru dalam mengajar tanpa kehadiran siswa, kegiatan belajar mengajar tidak akan berjalan lancar atau berjalan dengan baik. Guru dan siswa merupakan komponen yang tidak bisa dipisahkan dalam kegiatan pembelajaran.

Dari hasil penelitian dan pembahasan bahwa penggunaan model pembelajaran Two Stay-Two Stray (TS-TS) dapat meningkatkan prestasi belajar peserta didik pada mata pelajaran Fiqih sebagai mana telah dijabarkan dari hasil penelitian yang telah dilakukan peneliti di Madrasah Ibtidaiyah Nurul Iman NW Kembang Kerang ini, sehingga semakin menguatkan bahwa dengan menggunakan model pembelajaran Two Stay-Two Stray (TS-TS) ini mampu menarik perhatian serta minat siswa sehingga menghasilkan prestasi belajar yang meningkat.

Adapun tahapan kegiatan yang dilalui dalam proses penelitian ini adalah sebagai berikut :

\section{Siklus I}

\section{a. Perencanaan}

Peneliti bersama guru menyiapkan Rencana Pelaksanaan Pembelajaran (RPP) tentang pelajaran fiqih materi tentang Haji. Selain itu pada siklus ini juga guru bersama peneliti menyiapkan fasilitas dan sarana sesuai kebutuhan pembelajaran berupa kertas karton dan gambargambar, dan kemudian membuat lembar aktivitas guru dan siswa. Kemudian menyiapkan evaluasi beruapa tes dalam bentuk essay yang di jawab oleh siswa yang terdiri dari 10 soal yang di berikan kepada peserta didik .

1) (RPP) siklus I pada pelajaran yang menerapkan metode Two Stay-Two Stray (TS-TS).

2) Menyusun lembar observasi aktivitas guru dan peserta didik

3) Lembar hasil rekapitulasi nilai tes siklus I

\section{b. Pelaksanaan Tindakan Siklus I}

Dalam pelaksanaan tindakan ini peneliti melaksanakan kegiatan pembelajaran sesuai dengan skenario pembelajaran yang telah dibuat.

\begin{tabular}{|c|l|c|c|}
\hline No & \multicolumn{1}{|c|}{ Indikator } & Skor & $\begin{array}{c}\text { Rata -rata } \\
\text { Skor }\end{array}$ \\
\hline 1 & $\begin{array}{l}\text { Antusias peserta didik dalam } \\
\text { mengikuti kegiatan } \\
\text { pembelajaran. }\end{array}$ & 4 & 1,3 \\
\hline 2 & $\begin{array}{l}\text { Interaksi peserta didik dengan } \\
\text { guru }\end{array}$ & 3 & 1 \\
\hline 3 & $\begin{array}{l}\text { Kerjasama kelompok dalam } \\
\text { diskusi }\end{array}$ & 8 & 2,6 \\
\hline 4 & $\begin{array}{l}\text { Intraksi peserta didik Dengan } \\
\text { peserta didik }\end{array}$ & 9 & 3 \\
\hline 5 & $\begin{array}{l}\text { Aktivitas Siswa Dalam } \\
\text { Mengerjakan soal }\end{array}$ & 6 & 2 \\
\hline & Total skor 30 & \multicolumn{2}{|c|}{ cukup aktif } \\
\hline & Rata-rata Skor & \multicolumn{2}{|c|}{} \\
\hline & Kategori
\end{tabular}

Peneliti sebagai pengajar dan guru mengamati proses yang dilakukan dalam proses pelaksanaan tindakan siklus I yang diikuti oleh 16 orang peserta didik.

\section{Pertemuan Pertama}

Tahapan penggunaan metode ini adalah pembelajaran menggunakan lembar kegiatan yang berisi tugas-tugas yang harus dipelajari oleh tiaptiap siswa dalam satu kelompok. Setelah menerima lembar kegiatan yang berisi permasalahanpermasalahan yang berkaitan dengan konsep materi dan klasifikasinya, siswa mempelajarinya dalam kelompok kecil (4 siswa) yaitu mendiskusikan masalah tersebut bersama-sama anggota kelompoknya. Masing-masing kelompok menyelesaikan atau memecahkan masalah yang diberikan dengan cara mereka sendiri. Kemudian 2 dari 4 anggota dari masing-masing kelompok meninggalkan kelompoknya dan bertamu ke kelompok lain sedangkan 2 anggota yang tinggal dalam kelompok bertugas menyampaikan hasil kerja dan informasi mereka ke tamu. Setelah memperoleh informasi dari 2 yang tinggal, tamu mohon diri dan kembali ke kelompok masingmasing dan melaporkan hasil-hasil kerja mereka.

Setelah belajar dalam kelompok dan menyelesaikan permasalahan yang diberikan salah satu kelompok mempresentasikan hasil diskusi kelompok lainnya. Kemudian guru membahas dan mengarahkan siswa ke bentuk formal.

Pada tahap evaluasi ini untuk mengetahui seberapa besar kemampuan siswa dalam 
memahami materi yang telah diperoleh dengan menggunakan model pembelajaran model To Stay -To Stray (TS-TS). Masing-masing siswa diberi kuis yang berisi pertanyaan-pertanyaan dari hasil pembelajaran dengan model Two Stay -Two Stray (TS-TS), yang selanjutnya dilanjutkan dengan pemberian penghargaan kepada kelompok yang mendapatkan skor rata-rata tinggi. dikegiatan akhir guru menutup pelajaran memberikan tugas rumah dan berdo'a karena waktu telah habis. Pertemuan Kedua

Pertemuan kedua dilaksanakan peneliti membagi lembar soal fiqih, untuk mengukur tingkat kemampuan peserta didik memahami dan mengingat materi kemarin, kemudian siswa deberi tugas menjawab soal essay kurang lebih selama 70 menit.

\section{Hasil Observasi Siklus I}

\section{Aktivitas peserta didik}

Data aktivitas peserta didik pada siklus I. Secara lengkap, hasil observasi aktivitas peserta didik dapat dilihat pada tabel:

Hasil Analisis Observasi Aktifitas Peserta Didik siklus I.

Terlihat dari hasil Observasi belajar peserta didik siklus I tersebut, terlihat bahwa skor ratarata yang di peroleh adalah 10 dengan kategori cukup aktif. Oleh karena itu perlu diadakan perbaikan pada siklus II, kerena aktivitas peserta didik tergolong masih cukup aktif.

\section{Aktivitas guru}

Data lengkap mengenai aktivitas guru selama proses pembelajaran dengan menerapkan model pembelajaran Two stay-two stray (TS-TS) pada siklus I. Data lengkap aktivias guru dapat di lihat pada tabel :

Hasil Analisis Observasi Aktifitas Guru siklus I.

\begin{tabular}{|c|l|c|}
\hline No & \multicolumn{1}{|c|}{ Aspek yang diamati } & Skor \\
\hline 1 & Kegiatan persiapan & 2 \\
\hline 2 & Kegiatan inti pembelajaran & 2 \\
\hline 3 & Kegiatan akhir pembelajaran & 1 \\
\hline & Jumlah & $\mathbf{5}$ \\
\hline
\end{tabular}

Dari data tersebut terlihat bahwa skor yang diproleh guru adalah 5 dan tergolong dalam kategori cukup aktif, dapat dilihat pada ( lampiran 7).

\section{a) Data Prestasi Belajar}

Berikut ini adalah tabel prestasi belajar peserta didik dalam mata pelajaran fiqih. Dapat di lihat pada (Lampiran 11). Setelah dilakukan kegiatan pembelajaran dengan menggunakan metode two stay-two stray (TS-TS). Pada pertemuan kedua dilakukan evaluasi peserta didik, Evaluasi berlangsung kurang lebih selama 70 menit, Evaluasi dilakukan dengan memberi tes yang terdiri dari 10 soal essay. Kemudian nilai yang sudah didapatkan dikalkulasikan sehingga mendapatkan Analisis data hasil evaluasi belajar fiqih akan menghasilkan ketuntasan individual dan ketuntasan klasikal, serta nilai rata-rata kelas.

Prestasi Belajar Siswa Dalam Mata Pelajaran FIQIH Siklus I

\begin{tabular}{|l|l|c|}
\hline No & Aspek yang diukur & $\begin{array}{c}\text { Keterangan } \\
\text { (dalam } \\
\text { angka) }\end{array}$ \\
\hline 1 & $\begin{array}{l}\text { Jumlah peserta didik yang ikut } \\
\text { evaluasi }\end{array}$ & 16 \\
\hline 2 & $\begin{array}{l}\text { Banyak peserta didik yang tuntas } \\
\text { (peserta didik yang mencapai nilai } \geq\end{array}$ & 10 \\
\hline 30 ) & $\begin{array}{l}\text { Banyak peserta didik yang belum } \\
\text { tuntas (peserta didik yang nilainya }< \\
70)\end{array}$ & 6 \\
\hline 4 & Persentase ketuntasan klasikal & $62,5 \%$ \\
\hline 5 & Jumlah skor keseluruhan & 1,130 \\
\hline 6 & Nilai rata-rata kelas & 70,62 \\
\hline
\end{tabular}

b) Nilai rata-rata kelas

$$
\begin{aligned}
& \mathrm{R}=\frac{\Sigma X}{N} \\
& =\frac{1,130}{16} \\
& R=70,62
\end{aligned}
$$

c) Ketuntasan klasikal

$$
\begin{array}{rl}
\mathrm{KK} & =\frac{P}{N} \times 100 \\
\frac{10}{16} \times & 100 \\
\mathrm{~K} & k=62,5 \%
\end{array}
$$

Tabel di atas memperlihatkan hasil evaluasi ketuntasan individual dan klasikal 16 siswa. Sebanyak 10 siswa telah mencapai nilai standar ketuntasan dan 6 siswa belum mencapai nilai standar ketuntasan. Maka dari hasil ketuntasan individual tersebut dapat diperoleh ketuntasan klasikal sebesar 62,5\% Pada ketuntasan belajar, suatu penilaian dikatakan tuntas secara klasikal apabila persentasi siswa yang memperoleh nilai $\geq$ 70 sebesar $85 \%$ dari siswa yang mengikuti evaluasi. Maka dapat disimpulkan bahwa pada siklus pertama ini siswa yang mengikuti tindakan belum tuntas secara klasikal.

Nilai rata-rata kelasnya adalah 70,62 yang diperoleh dari jumlah nilai seluruh peserta didik sebesar 1,130 dibagi dengan jumlah siswa yang mengikuti evaluasi dan tindakan sebanyak 16 siswa. Sedangkan nilai pada observasi awal ratarata kelas yaitu 69,06 yang diperoleh dari jumlah nilai peserta didik sebesar 1,105.. Jadi nilai ratarata kelas setelah penggunaan metode two staytwo stray (TS-TS) lebih tinggi dari nilai rata-rata siswa sebelum menggunakan metode ceramah saja. Hal ini menunjukan bahwa terjadi 
peningkatan hasil belajar setelah metode ini diterapkan.

d) Refleksi Siklus I

Berdasarkan data hasil penelitian, dapat disimpulkan bahwa pelaksanaan siklus I ini belum mencapai indikator kerja dari penelitian. Dengan demikian perlu diadakan perbaikan tindakan pada siklus berikutnya yaitu siklus II.

Dilihat dari analisis siklus I, terlihat bahwa rata-rata prestasi belajar peserta didik berada pada kategori cukup aktif. Aktivitas peserta didik dan guru juga masih berkategori cukup aktif. Hal ini menunjukkan bahwa semuanya belum mencapai indikator kerja dalam penelitian. Karena tindakan dianggap mencapai indikator jika aktivitas guru berada pada kategori aktif, sehingga pada siklus berikutnya perlu dilaksanakan peningkatan terhadap kekurangan yang terjadi pada siklus I.

Adapun kekurangan-kekurangan yang terjadi adalah :

1) Dengan menggunakan metode ini membutuhkan waktu yang panjang, pada siklus I ini terlihat guru masih belum mampu menggunakan waktu dengan sebaik-baiknya, sehingga pada saat membuat kesimpulan guru masih kurang membimbing peserta didik, karena keterbatasan waktu.

2) Metode ini membutuhkan intraksi yang tepat dan pengelolaan kelas yang baik, pada siklus ini guru belum menguasai kelas sepenuhnya sehingga menyebabkan peserta didik masih ada yang melamun dan bermain sendiri dengan temannya.

3) permaianan yang kurang menarik. Menggunakan metode ini harus bisa memilih permainan yang tepat untuk peserta didik, pemilihan permainan yang salah juga dapat menjadi kekurangan pada metode ini.

Perbaikan yang akan dilakukan pada siklus II adalah :

1) Memanfaatkan waktu dengan sebaik-baiknya agar skenario pembelajaran bisa terlaksana dengan baik dan semua langkah-langkah pembelajaran bisa terlaksana.

2) Disamping itu, guru harus mampu mengolah kelas dengan baik seperti memberikan penguatan dengan cara berkeliling kepada anak-anak yang perlu mendapat perhatian lebih dari guru.

3) Mencari permainan yang lebih menarik.

e) Siklus II

1 Perencanaan

Perencanaan tindakan pada siklus II ini, tidak jauh berbeda dengan siklus I, hanya saja pada siklus II ini dilakukan perbaikan kekurangan pada siklus I. pada siklus ini juga bersama peneliti menyiapkan, fasilitas dan sarana sesuai kebutuhan pembelajaran berupa media gambar, dan lembar observasi aktivitas guru dan aktivitas siswa mampu melaksanakan kegiatan belajar sesuai dengan Rencana Pelaksanaan Pembelajaran (RPP), kemudian menyiapkan evaluasi berupa tes dalam bentuk essay yang di jawab oleh peserta didik, yang terdiri dari 10 soal pertanyaan yang di berikan kepada peserta didik.

Rincian hasil perencanaan siklus II yaitu :

1) Rencana Pelaksanaan Pembelajaran (RPP) siklus II pada pembelajaran yang menerapkan model pembelajaran Two Stay-Two Stray (TSTS).

2) Menyusun lembar observasi aktivitas guru dan siswa

3) Lembar hasil rekapitulasi nilai tes tulis siklus II.

2 Pelaksanaan Tindakan

1) Pertemuan ke - 1

Adapun materi pembelajaran siklus II pada pertemuan ini yakni Amalan Haji, larangan selama berhaji dan pembayaran DAM (Denda), Tata Cara Haji, hanya saja langkah-langkah pembelajaran siklus II telah disesuaikan dengan rekomendasi yang telah ditentukan pada siklus sebelumnya. Pada waktu melakukan apersepsi peserta didik terlihat sangat semangat, tidak ada lagi peserta didik yang lemas dan malas belajar dan peserta didik yang main-main sudah bisa diatasi. Ketika guru mengajukan pertanyaan-pertanyaan yang memancing peserta didik untuk mengingat pelajaran sebelumnya, antusiasnya ditandai dengan munculnya keberanian peserta didik mengacungkan tangan sendirinya untuk menjawab pertanyaan dari guru dan mereka menjawab dengan tertib. Ini menandakan kecanggungan (ketidak percayaan diri) dan rasa malu mereka sudah berkurang, peserta didik aktif dalam bertanya, peserta didik disiplin dalam mengikuti pelajaran.

Setelah guru melakukan apersepsi dan motivasi agar lebih semangat belajar, dengan itu peserta didik siap mengikuti pelajaran yang akan disampaikan oleh ibu gurunya, menggunakan teknik bermain sambil belajar dengan menggunakan motode pembelajaran two stay-two stray (TS-TS), peserta didik akan mengingat dan mampu menceritakan kembali kepada temantemanya, selanjutnya guru membagi mereka menjadi 4 kelompok, masing-masing kelompok mempersentasikan hasil kerja mereka pada tamu yang berkunjung, dan mereka menjelaskan maksut dari media gambar yang mereka buat, peserta 
didik pun aktif mendengarkan temannya yang mempersentasikan hasil kerjanya selain itu teman tamu juga aktif menulis hasil dari apa yang mereka dengarkan untuk dilaporkan kembali ke kelompok masing-masing.

Keaktifan siswa tersebut disebabkan oleh guru melakukan pengontrolan dan bimbingan secara berkelompok dan mencoba memperbanyak kunjungan ke kelompok kelompok ketika peserta didik sedang belajar secara kelompok. Guru memperhatikan para peserta didik yang sedang sibuk mengunjungi masing-masing kelompok secara bergiliran.

Setelah peserta didik berhasil mendapatkan info secara bergilir guru memberikan waktu untuk masing-masing kelompok mengomentari kelompok yang lain, kemudian mengajak siswa bermain teka-teki yang berisi soal-soal terkait dengan materi yang di pelajari setiap kelompok yang paling cepat menemukan dan menyelesaikan soal-soal yang ada akan mendapatkan hadiah. Selanjutnya guru memberikan penguatan mengenai hal-hal yang belum jelas dan konsentrasi peserta didik masih terlihat, pada saat guru mengajukan pertanyaan peserta didik sangat antusias menjawab kelas terlihat sangat ramai walaupun ada beberapa peserta didik yang tidak aktif. Ketidak aktifan mereka karena memang tipe mereka tertutup dan pendiam.

Oleh sebab itu kegiatan pembelajaran pada siklus ini peserta didik mampu soal teka-teki dengan baik. Sebagai alat bantu untuk bisa belajar memahami sebuah materi. Maka dari itu pada siklus dua ini sudah terjadi peningkatan pemahaman peserta didik.

Setelah peserta didk keluar kelas guru mengisi lembar observasi, mengevaluasi lagi kegiatan yang dilakukan guru ketika proses pembelajaran berlangsung.

2) Pertemuan ke - 2

Pada pertemuan kedua ini langkah-langkah yang digunakan hampir sama dengan pertemuan kedua pada siklus I, peneliti membagi lembar soal fiqih, berupa tes tulis.

\section{Hasil Observasi}

\section{a) Aktivitas peserta didik}

Data lengkap mengenai aktivitas belajar peserta didik pada siklus II selama proses pembelajaran dengan menerapkan metode two stay-two stray (TS-TS) dapat dilihat pada (Lampiran 10). Dari data hasil observasi belajar peserta didik siklus II tersebut, terlihat bahwa skor rata-rata yang diperoleh adalah 14,8 dengan kategori aktif. Oleh karena itu tidak perlu diadakan perbaikan.
Hasil Analisis Observasi Aktivitas Siswa siklus II

\begin{tabular}{|c|l|c|c|}
\hline No & \multicolumn{1}{|c|}{ Indikator } & Skor & $\begin{array}{c}\text { Rata-rata } \\
\text { Skor }\end{array}$ \\
\hline 1 & $\begin{array}{l}\text { Antusias peserta didik dalam } \\
\text { mengikuti kegiatan pembelajaran }\end{array}$ & 7 & 2,3 \\
\hline 2 & $\begin{array}{l}\text { Interaksi peserta didik dengan } \\
\text { guru }\end{array}$ & 6 & $\mathbf{2}$ \\
\hline 3 & $\begin{array}{l}\text { Kerjasama Kelompok Dalam } \\
\text { Diskusi }\end{array}$ & 11 & $\mathbf{3 , 6}$ \\
\hline 4 & $\begin{array}{l}\text { Intraksi peserta didik Dengan } \\
\text { peserta didik }\end{array}$ & 11 & $\mathbf{3 , 6}$ \\
\hline 5 & $\begin{array}{l}\text { Aktivitas peserta didik Dalam } \\
\text { Mengerjakan soal }\end{array}$ & 10 & $\mathbf{3 , 3}$ \\
\hline & Total skor & \multicolumn{2}{|c|}{14,8} \\
\hline & Rata-rata Skor & Aktif \\
\hline & Kategori & \multicolumn{2}{|c|}{} \\
\hline
\end{tabular}

Berdasarkan tabel diatas terlihat bahwa ratarata aktivitas siswa yaitu 14,8 dan berkatagori aktif. Jadi dapat dikatakan bahwa aktivitas belajar peserta didik pada siklus II ini meningkat yaitu dari rata-rata 10 pada siklus I meningkat menjadi 14,8 pada siklus II dan yang berkatagori cukup aktif menjadi berkatagori aktif. Tabel tentang hasil analisis observasi aktivitas siswa diatas menunjukkan bahwa aktivitas siswa dalam mengikuti pembelajaran mengalami peningkatan yang cukup signifikan, apabila proses pebelajaran sudah baik maka akan berdampak pada hasil dan tingkat prestasi belajar yang baik pula.

\section{a) Data hasil tes}

Data hasil belajar siswa siklus II dapat dilihat pada tabel berikut (Lampiran 12). Sebagaimana evaluasi pada siklus pertama, maka di siklus kedua ini evaluasi dilakukan pada pertemuan ke empat dalam siklus kedua, evaluasi berlangsung selama 70 menit, Soal tes tulis terdiri dari 10 soal essay. Adapun hasil belajar peserta didik pada siklus kedua ini dapat dilihat pada tabel berikut :

\begin{tabular}{|l|l|c|}
\hline No & \multicolumn{1}{|c|}{ Aspek yang diukur } & $\begin{array}{c}\text { Keterangan } \\
\text { (dalam angka) }\end{array}$ \\
\hline 1 & Jumlah siswa yang ikut evaluasi & 16 \\
\hline 2 & $\begin{array}{l}\text { Banyak siswa yang tuntas } \\
\text { siswa yang mencapai nilai } \geq \\
70)\end{array}$ & 16 \\
\hline 3 & $\begin{array}{l}\text { Banyak siswa yang belum } \\
\text { tuntas (siswa yang nilainya < } \\
70)\end{array}$ & 0 \\
\hline 4 & Persentase ketuntasan klasikal & $100 \%$ \\
\hline 5 & Jumlah skor keseluruhan & 1,340 \\
\hline 6 & Nilai rata-rata kelas & 83,75 \\
\hline 7 & Kategori & Tuntas \\
\hline
\end{tabular}

Tabel 4.9: Hasil Evaluasi Belajar Siswa Siklus II

a) Nilai rata-rata kelas

Ketuntasan klasikal ini menunjukkan peningkatan dari siklus sebelumnya sebesar 68,75 $\%$, maka hasil belajar dapat dikatakan tuntas secara klasikal dilihat dari persentase evaluasi 
hasil ketuntasan klasikal yang telah ditentukan, yaitu $85 \%$.

Nilai rata-rata hasil evaluasi siswa adalah 83,75 diperoleh dari jumlah nilai seluruh siswa sejumlah 1,340 dibagi dengan jumlah siswa yang mengikuti evaluasi dan tindakan sebanyak 16 siswa. Hasil rata-rata tersebut memperlihatkan peningkatan dari siklus pertama setelah diadakan refleksi.

b) Refleksi

Hasil yang dicapai pada siklus II menunjukkan bahwa persentase prestasi belajar peserta didik meningkat dan bisa disimpulkan bahwa prestasi peserta didik pada mata pelajaran fiqih meningkat pula secara segnifikan karena siklus II ini telah mencapai target yang diharapkan, sehingga tidak perlu dilanjutkan ke siklus III.

\section{Pembahasan}

Penelitian ini dilaksanakan dalam II siklus yaitu siklus I dilaksanakan dalam 2 kali pertemuan, dengan tes evaluasi dilakukan pada pertemuan ke2. Dari hasil observasi diperoleh data kualitatif yang akan memberikan gambaran tentang kegiatan yang dilakukan oleh guru dan peserta didik selama proses belajar mengajar, dan data kuantitatif diperoleh dari hasil tes belajar peserta didik yang berupa nilai rata-rata hasil belajar peserta didik.

Berdasarkan hasil persentase prestasi, observasi dan evaluasi yang dilakukan pada siklus I, rata-rata prestasi belajar dan aktivitas peserta didik sudah tergolong cukup aktif yaitu dengan rata-rata prestasi belajar peserta didik 70,62 dan aktivitas peserta didik yaitu 10 dari 1 kali pertemuan pada siklus I, aktivitas peserta didik masih kurang nampak, karena kurangnya penguasaan kelas oleh guru sehingga skor aktivitasnya tegolong masih cukup aktif. Dengan penerapan model pembelajaran Two Stay-Two Stray (TS-TS), khususnya di kelas V Madrasah Ibtidaiyah Nurul Iman NW Kembang Kerang, peserta didik ikut terlibat secara langsung di dalam proses pembelajaran. Pembelajaran metode Two Stay-Two Stray (TS-TS) adalah tipe pembelajaran yang mengajar peserta didik lebih aktif dan mampu mengingat lebih lama. Tahap yang dilalui oleh guru dengan belajar menggunakan model pembelajaran Two Stay-Two Stray (TS-TS) yaitu sebagaimana telah dipaparkan pada bagian sebelumnya, terdiri dari kegiatan awal, kegiatan inti dan kegiatan akhir (penutup).

Pada tahap kegiatan awal, guru melakukan apersepsi (meningkatkan kembali) siswa terhadap pelajaran sebelumnya, atau juga menggali kamampuan awal siswa. Tahapan berikutnya adalah memberikan kepada siswa untuk menemukan sendiri maksut atau pengertian dari gambar yang sudah ada. Dengan teknik tersebut, pada kegiatan belajar siswa sehingga ada aktivitas siswa yang hanya tidak mendengarkan, mencatat apa yang di berikan oleh guru, Begitu juga dengan aktivitas guru dalam pembelajaran tergolong dalam kategori cukup aktif dengan skor 5. Namun masih terdapat kekurangan-kekurangan dimana kekurangan itu ada yang berasal dari guru dan ada yang berasal dari siswa.

Pada siklus I, aktivitas siswa dalam pembelajaran yang masih kurang walaupun sudah tergolong cukup aktif tetap juga mempengaruhi prestasi belajar. Hal ini disebabkan oleh sebagian siswa yang tidak memperhatikan penjelasan guru pada saat menyampaikan materi, masih kurang intraksi antara siswa dengan siswa lain, intraksi guru dengan siswa masih kurang sehingga aktivitas siswa masih kurang. Walaupun intraksi masih tergolong cukup aktif akan tetapi aktivitas siswa tidak menoton lagi walaupun masi kurang. Ini disebabkan karena siswa kebanyakan bermain, di saat guru menyuruh siswa, siswa masih malumalu untuk maju didepan kelas, pada saat giliran maju didepan kelas untuk memaparkan hasil kerja kelompoknya. Sedangkan rata-rata nilai hasil belajar siswa yang diperoleh adalah 70,62 dan ketuntasan secara klasikal 62,5\%.

Dari hasil evaluasi pada pelaksanaan tindakan siklus II yang dilakukan diperoleh bahwa terjadi peningkatan peroses pembelajaran terdapat peserta didik maupun guru. Hal ini terlihat dari hasil observasi terhadap kegiatan guru dan peserta didik yang sudah termasuk kategori sangat aktif. Bagi siswa yakni dapat meningkatkan kreativitas siswa dalam proses pembelajaran, dimana dapat terlihat pada kerjasama peserta didik dalam menyelesaikan soal teka-teki. Selain itu peserta didik semakin berani bertanya kepada guru tentang apa yang belum dipahami, peserta didik juga semakin termotivasi untuk belajar dan menyelesaikan permainan dengan baik.

Kekurangan dari guru antara lain belum terlaksananya semua komponen dalam skenario pembelajaran yaitu masih kurang membimbing siswa dalam membuat kesimpulan akhir pembelajaran. Hal ini dikarenakan guru belum dapat mengatur waktu sebaik mungkin, guru terlalu banyak memberikan waktu pada peserta didik. Kegiatan akhir hanya dilakukan seadanya tanpa mengarahkan peserta didik untuk menyimpulkan materi pelajaran dan untuk memberikan pekerjaan rumah pada siswa.

Hal-hal yang harus diperbaiki pada tindakan siklus II adalah guru memberikan beberapa pertanyaan sehingga dapat terciptanya komunikasi 
antara peserta didik dengan guru, guru juga harus mampu mengelola waktu dengan efesien agar semua tahapan kegiatan dalam skenario pembelajaran dapat terlaksana dan dapat membimbing siswa di dalam membuat kesimpulan akhir pembelajaran.

Pada tindakan siklus II, model pembelajaran Two Stay-Two Stray (TS-TS) kembali dilaksanakan. Berdasarkan hasil observasi pada tindakan siklus II, kegiatan guru dalam melaksanakan proses pembelajaran telah meningkat. Kekurangan yang terjadi pada siklus I sudah dapat diperbaiki. Peserta didik sudah lebih memperhatikan penjelasan guru sehingga peserta didik mau mengajukan pertanyaan yang belum dipahami tentang materi yang diajarkan.

Hasil penelitian pada siklus I belum mencapai indikator, karena itu harus dilanjutkan pada siklus II. Pelaksanaan pembelajaran siklus II dilaksanakan dengan melakukan perbaikanperbaikan pada kekurangan dalam siklus I di antaranya, membimbing dan memotivasi peserta didik dalam menyelesaikan poster dengan kelompoknya dan bermain permainan yang sudah diberikan oleh guru, menghimbau peserta didik yang kurang aktif agar tidak malu menanyakan materi yang kurang dipahami, menyuruh peserta didik maju untuk membacakan hasil diskusi mereka memecahkan soal yang dibuat dalam bentuk teka-teki, peserta didik juga mulai berani mengungkapkan pendapatnya walaupun masih kurang dari yang diharapkan oleh peneliti, dan membimbing peserta didik dalam membuat kesimpulan materi.

Peningkatan tersebut disebabkan oleh beberapa faktor yaitu peserta didik berusaha memperhatikan penjelasan guru, peserta didik berusaha menjawab setiap pertanyaan yang diberikan oleh guru, peserta didik yang kurang bisa mau bertnya kepada peserta didik yang lebih bisa, peserta didik yang di suruh maju berusaha untuk memaparkan hasil diskusi mereka. Kerjasama antar teman kelompok sudah tercipta sehingga terjadi interaksi antara siswa dengan siswa. Hal ini juga tidak terlepas dari aktivitas guru yang sudah mampu memperbaiki kekurangannya pada siklus I. Pada siklus II ini juga terjadi peningkatan pada skor rata-rata aktivitas guru yaitu 9 yang tergolong kategori aktif. Guru aktif membimbing siswa sehingga terciptanya intraksi didalam pembelajaran serta mengatur intraksi antar siswa, dan skor rata-rata aktivitas peserta didik dan guru pada tindakan siklus II ini, sudah mencapai indikator keberhasilan penelitian yang telah ditetapkan maka penelitian ini tidak dilanjutkan dan berhenti pada siklus II.
Hasil pembelajran siklus II lebih baik jika dibandingkan dengan hasil pembelajaran siklus I. Pada siklus II, skor aktivitas belajar siswa yang diproleh telah berada pada kategori aktif dengan nilai skor meningkat menjadi 14,8, sedangkan ratarata nilai hasil belajar siswa yang diperoleh adalah 83,75 dengan jumlah siswa yang mengikuti tes 16 peserta didik dan melihat rata-rata hasil belajar peserta didik secara klasikal adalah 100\%. Keaktifan peserta didik selama proses belajar mengajar berlangsung membantu dalam pencapaian hasil belajar siswa.

\section{SIMPULAN DAN SARAN}

Dari hasil penelitian dan pembahasan dapat disimpulkan bahwa:

Penggunaan model pembelajaran Two StayTwo Stray (TS-TS) dapat meningkatkan prestasi belajar peserta didik pada mata pelajaran Fiqih Dimana pada siklus satu kegiatan guru dan siswa berkategori cukup aktif sehingga guru harus memperbaiki pada siklus II yang berkategori aktif.

Hasil penelitian menunjukkan bahwa dari persentasi peserta didik yang memiliki prestasi berkategori tinggi meningkat dari 10 pada siklus I menjadi 14,8 pada siklus II, dan prestasi belajar peserta didik yang terdiri dari 16 jumlah peserta didik terdapat 10 peserta didik berhasil mencapai nilai $\geq 70$ dengan presentasi ketuntasan klasikal $62,5 \%$ dan rata-rata hasil belajar 70,62. Sementara pada siklus II diperoleh data ketuntasan klasikal sebesar $100 \%$ atau 16 peserta didik memperoleh nilai $\geq 70$ dengan rata-rata hasil belajar 83,75. Hasil observasi juga menunjukkan aktivitas peserta didik dan guru mengalami peningkatan dari siklus I ke siklus II, pada siklus I aktivitas peserta didik dan guru berkategori cukup aktif, sedangkan pada siklus II aktif.

\section{E. SARAN}

Bagi Madrasah khususnya guru bimbingan kelas $\mathrm{V}$ yang mengajarkan Fiqih agar mau menerapkan model pembelajaran Two Stay-Two Stray (TS-TS) sehingga dapat meningkatkan prestasi belajar peserta didik meningkat.

a. Madrasah diharapkan memberikan evaluasi terhadap guru dalam pelaksanaan pembelajaran.

b. Guru supaya memberikan masukan yang berarti/bermakna pada Madrasah dalam rangka perbaikan atau peningkatan pembelajaran.

Bagi peneliti selanjutnya agar mengembangkan penelitian yang lebih bagus. 
30 Ibtida'iy : Jurnal Prodi PGMI | Vol. 6, No. 2, Oktober 2021, hal. 19-30

\section{DAFTAR RUJUKAN}

Abdul Hadis Dan Nurhayati, Psikologi Dalam Pendidikan (bandung; alfabeta; februari 2014)

Abuddin nata, Masail Al-Fiqihiyah (Jakarta; Kencana; oktober 2012) Agus Suprijono, Cooverative Learning Teori Dan Aplikasipaikem (yogyakarta; pustakapeajar; agustus 2009)

Dokumentasi, di petik dari profil MI Nurul Iman NW Kembang Kerang, 4 april 2018.

Mappanyompa. (2019). Problematika Pengkaderan Di Perguruan Tinggi Muhammadiyah Mataram Dalam Perspektif Norma Pengkaderan Muhammadiyah, Media Keadilan: Jurnal Ilmu Hukum, 10 (1), 82-98

H. Ishak Abdulhak, Ugi Suprayogi, Penelitian Tindakan Dalam Pendidikan Nonformal (Jakarta; Rajawali Press; 2012)

Hamzah B.Uno Dkk, Menjadi Peneliti PTK Yang Professional, (jakarta; PT. Bumi Aksara; april 2012)

Isjoni, Cooperative Learning Efektivitas Pembelajaran Kelompok (Bandung; alfabeta; april)

Jasa ungguh muliawan, 45 model pembelajaran spektakuler (Yogyakarta; Ar-Ruzz Media; 2016)

Johni Dimyati, Metodologi Penelitian Pendidikan Dan Aplikasinya, (jakarta; PT. Fajar interpratama mandiri; mei 2013)

Lif khoiru Ahmadi dan Sofan Amri, Pengembangan Dan Model Pembelajaran Tematik

Nana sudjana, Dasar-dasar proses belajar mengajar, ( bandung; Sinar Baru Argesindo; November 2014)

Nana Sudjana, Penilaian Hasil Proses Belajar Mengajar ( Bandung: remaja rosdakarya. 2013)

Nana Sudjana, Penilaian Hasil Proses Belajar Mengajar, (Bandung ; PT Remaja Rosdakarya; 2017)

Oemar Hamalik, Kurikulum Dan Pembelajaran (Jakarta; PT Bumi Aksara; oktober 2011)

Roestiyah, Strategi Belajar Mengajar, (Jakarta; PT Rineka Cipta; oktober 2012

Rusman, Pembelajaran Tematik Terpadu, (Jakarta; PT Raja Grafindo Persada; juni 2015).

Mappanyompa. (2020). Penggunaan Media Tiga Dimensi Dalam Meningkatkan Hasil Belajar Atematika Siswa, Ibtida'iy Journal PGMI, 4 (2), 104-110.

Saefullah, psikologi perkembangan dan pendidikan,(bandung; CV Pustaka Setia;oktober 2012) Sitepu, Pengembangan
Sumber Belajar, (Jakarta; PT Raja Grafindo Persada; juni 2014)

Syaiful Bahri djamarah, Prestasi Belajar dan Kompetensi Guru, (Surabaya: Usaha Nasional, 2012) 